\title{
Hygiene habits and carriers in families with a child who has had typhoid fever*
}

\author{
Hábitos de higiene e portadores em familias que tiveram uma criança com \\ febre tifóide
}

\author{
M. de la Luz Alvarez**, Fanny Wurgaft"*, Julio Espinoza**, Magdalena Araya**, Guillermo \\ Figueroa**
}

\begin{abstract}
ALVAREZ, M.L. et al. Hygiene habits and carriers in families with a child who has had typhoid fever. Rev. Saúde pübl., S. Paulo, 26: 75-81, 1992. The relationship between asymptomatic shedding of bacterial enteropathogens and the hygiene habits of families who have had a child with typhoid fever (TF) are investigated. The sample was made up of 80 families: 40 families in which one child had had TF (Group A) and 40 in which no children or either of the parents had had a history of TF (Group B). In each group 20 families belonged to a low socieconomic status (SES) and 20 to a high SES. A structured interview was used to evaluate the SES and the hygiene habits of the child; observations were made to measure the hygiene habits of the family (toilet, kitchen and food preparation) and bacteriological studies (fecal samples and hand markers). Results show that carriers were more frequent in Group A than in Group B. The bacterial species found were significantly more numerous in Group A than in Group B (fecal samples: E. coli, the classic serotypes, Shigella ssp, and hand markers: E. coli). Families of Group A had higher carriage rates than those of Group B. Finally there exists a significantly higher association between inadequate hygiene habits and carrier families. These results show the need to teach specific habits of proper hygiene to the entire population, because the fact of belonging to the high SES does not in itself preclude inadequate hygiene habits.
\end{abstract}

Keywords: Typhoid, epidemiology. Carrier state. Family. Hygiene.

\section{Introduction}

Typhoid fever (TF) has high incidence and prevalence in Chile, $22,23,26$ mainly in the Mctropolitan Area (Santiago and surroundings) where it is endemic ${ }^{6,18,30,32}$. In 1986, the incidence of TF in this country was $58.6 \times 10^{5}$ and of this 52.08 corresponded to the Metropolitan Arca ${ }^{24}$. This high rate has been attributed to the consumption of contaminated drinking water and food stuffs or to differences in the virulence of SALMONELLA typhi $i^{8}$ in some regions. Transmission of the disease occurs through the fecal-oral cycle, as in acute diarrhoea. In family studics on this latter condition, a high rate of asymptomatic carricrs in Santiago has been demonstrated, which has been interpreted as a consequence of the high microbiological contamination of the environment ${ }^{15,20,21}$.

Studies of carriers are seldom made because of their high costand the difficulty in obtaining fecal specimens

\footnotetext{
* Grant IDRC 3 P 840155

** Instituto de Nutrición y Tecnología de los Alimentos, Universidad de Chile
}

Separatas/Reprints: M. de la Luz Alvarez - Casilla 15138, Santiago 11, Chile. from adult family members $2,3,5,7,11,12,13,25$. The carriage rate of SALMONELLA typhi has been investigated in food handlers ${ }^{10,28,29}$ but no study has evaluated the family group as a possible contamination route.

Thus the purpose of this sludy was the investigation of the relationship between the presence of carricrs of cntcropathogenic bacterial agents and the quality of hygiene habits in families who had or had not had a child with TF.

\section{Material and Method}

The experimental design was "ex post facto"9. The sample was made up of 80 families: 40 familics in which a child had had TF in the last 6 months (Group A); 20 families, of low socieconomic status (SES) and 20 of high SES were choscn as also 40 familics in whom no child nor either parent had had a history of TF since they had started living together (Group B controls). The control children had not been immunized against TF; 20 of these families also belonged to the low SES and 20 to the high SES. Children were matched by age, school and grade; at the time of incorporation into this protocol, they had already been in scholl for one two years and their ages ranged 6.5 to 9 years. 


\section{Procedures for the obtaining of the sample}

Families were contacted personally at their homes after relevant information about the children had been obtained from the hospitals where patients stayed during their episode of typhoid fever, and/or from the schools which they altended.

Cases of TF were accepted when diagnosis had been made by a positive hemoculture and/or mieloculture and/or coproculture. A positive Widal test $(1 / 80)$ and/or a hemogram suggestive of TF were not accepted as alone constituting an adequate diagnosis, but only when corroborating the former criteria. In both groups controls were selected from among classmates who belonged to the same SES.

\section{Techniques}

- SES was evaluated during a structured interview by means of a score previously validated for our urban population ${ }^{1}$.

- Bacteriological studies: All members of the families were provided with toilet paper and trained in how to collect a fecal sample. These were obtained with a sterile cotton swab from recently voided feces present on the toilet paper. They were kept in Stuart transport medium until being processed in the laboratory ${ }^{17}$. The gathering period was over 2 years from January till December and no scasonal differences were found between the groups. All the bacteriological studies were undertaken at the Microbacteriological Laboratory of the "Inst. de Nutrición y Tecnología de Alimentos" of which one of the authors (G. Figueroa) is the director.

The following enteropathogens were investigated using routine techniques ${ }^{16,17,27,31}$ : Escherichia coli (Enteropathogenic classic serotypes (EPEC)), enterotoxigenic (ETEC) and invasive (EIEC) strains, Shigella, Salmonella, Campylobacter. Bacterial contamination of the hands was assessed in samples obtained by immersing the hands in a plastic glove containing Brain Heart culture broth. Collection of specimens was supervised by a member of our team. The study of enteropathogens was carried out by the use of the methods described above. In addition, a search was also made for Staphylococcus aureus.

- Hygienic habits were assessed during structured interviews and observations:

1) an interview with the child included casily understandable openended questions about use of the toilct and toilet paper, the washing of the hands after use of the toilet, before cating and the way of eating at home and at school.

2) the structured observations measured were: a) bathroom hygiene, which consisted in watching for the presence of feces or urine on the toilet seat, the toilet bowl, the floor around the toilet, and the uncovered toilet bowl. As for the bathroom sink, dirt adhering to it and dirty clothes left to soak in the bathtub or bidet were also observed; b) contaminating materials were also evaluated in the kitchen: whether the sink had dirt adhcring to it, had remains of vegetables or peels in it, whether the floor around the sink had remains of raw vegetable on it, and if the sink was cleaned with some detergent or other special product. Both observations described were made on the first visit, therefore when the family was not expecting to receive our visit; $c$ ) a second observation was carried out to evaluate food preparation: the act of food preparation was considered to begin when the person first took the items needed. It included the cleaning of the lable where these were handled and it ended at the time the food was put to cook. First "material hygicne" was obscrved. This was defined as the cleanliness of some particular objects (table, floor, uncovered garbage pail), whether the table was cleaned before beginning the operation, and whether flies were present on the set of utensils being used. Then, the preparation of the food as such, was evaluated: the washing of vegetables with running water, the washing of the hands with soap and drying them with a clean towel, the washing of the objects used and the way utensils were stored after washing. Both observations were carried out by two of the authors (Alvarez and Wurgaft), previously trained in the application of these tests. Reliability tests for the two observers gave results of above $90 \%$.

Cases and controls were assigned to each of them conseculively. Information was recorded as to whether cach behaviour was present or absent, in agreement with a previously accepted definition. No interpretation of data was made. If the indicator was absent it was omilted out and not taken into consideration in making up the index. It was explained to familics who agreed to participate that an important aspect of the study was to obscrve them when they were preparing a meal. Since individuals may change their behavior when they feel they are being observed, the women were told at the time that our main interest was the kind of recipes they were preparing, so that the focus of their attention would be on what they were doing and not on how they were doing it.

\section{Procedures}

Families who were willing to participate in the study, signed an agreement which detailed each procedure included in the study. The mother was 
then interviewed and she answered the socioeconomic survey. Later, the bathroom and kitchen were observed, always in the morning or after lunch. The child, if at home, was also interviewed and, if not, an appointment was made to see him/ her later. A date was also arranged so that the observation of the preparation of the main meal's (lunch) could be carried out.

Two fecal samples from each subject were obtained for bacteriological studies, after the observations and interviews had taken place.

\section{Data Analysis}

Information was analysed by means of the following indexes:

1 - SES, made up of 3 variables: schooling, occupation of the head of the household and housing. This latter variable is composed of 5 indicators (ownership of house, quality - materials and size -, water supply, sewage system and goods owned by the dwellers). These constitute a subindex, the housing score.

The total of the values obtained in the variables schooling, occupation and housing gives a score expressed on a scale from 1-6 points, of 1 bcing the highest and 6 the lowest. The sample studicd was between 1 and 2 for the group of high SES and 4 and 5 for the group of low SES.

2 - Purchase Index, made up of 4 indicators (frequency in the purchase of swcets and candy items which could be wrapped, not wrapped or wrapped at the time of purchase). Its maximum score was 8 and the minimum 0 , with the least number of points corresponding to the best quality of hygiene.

3 - Toilet Observation Index, made up of 5 indicators (toilet seat cover, dirty toilet bowl, open cover, toilet seat with feces, dirty floor around the toilet) considering the absence of dirty a positive result. These data were expressed as a percentage, $100 \%$ being for maximum hygiene.

4 - Sink Observation Index, made up of 4 indicators (adhcring dirt, food remainders, dirth floor, washing only with water or with specific products). These were handled similarly to the previous index (100\% for maximum hygiene).

5 - Washing of Hands (after touching something dirty) Index, was made up of 3 (sometimes 4) indicators (peeling potatoes, washing vegetables to which soil adheres - saltwort, spinach, lettuce... -, changing a baby's diapers or touching money, followed by washing with soap). Results were expressed in percentages as described for previous indexes.

6-Washing of items used during the preparation of lunch was made up of 3 indicators (the washing of utensils, after use, with detergent and/or a brush or other similar instrument). This was expressed in the same way as in the indexes previously described.

7 - General Food Preparation Index, made up of the sum of the following indicators: cleanliness of objects used in food preparation, "material hygiene", washing of vegetables, washing and drying of hands, washing of items, storage of utensils after washing. The percentage was calculated as previously described.

8 - The Family Carrier Index was made up of the number of members of the family members in whom an enteropathogen had been isolated in the stool cultures. The range observed was 1 (minimum) and 5 (maximum) enteropathogens for each family member. Thus, the families were grouped into "carrier" and "non-carrier families" depending on the presence or absence of enteropathogens in the stool cultures of their members.

9 - The "Fecal-Oral Cycle Index" was made up of the obscrvations made in the bathroom, the kitchen, the "material hygiene" in food preparation and the General Food Prcparation Index. Chi square, Fisher and Student tests were applied for the comparison of the groups.

\section{Results}

First, we wish to describe the sample which underwent a bacteriological study according to group and SES.

Table 1 shows the stool cultures of 527 individuals distributed by age and SES. No significant differences were found.

Table 1. Stool Cultures of 527 individuals of the low and high SES distributed by age in families with children who had $(A)$ or had not had (B) Typhoid Fever

\begin{tabular}{|c|c|c|c|c|c|}
\hline \multicolumn{6}{|c|}{ Socioeconomic Stratum } \\
\hline \multirow[b]{2}{*}{$\begin{array}{c}\text { Groups } \\
A G E \\
\text { (in years) }\end{array}$} & \multicolumn{2}{|c|}{ Low } & \multicolumn{2}{|c|}{ High } & \multirow[b]{2}{*}{$\begin{array}{c}\text { Total } \\
n \\
(\%)\end{array}$} \\
\hline & $\begin{array}{c}A \\
n \\
(\%)\end{array}$ & $\begin{array}{c}B \\
n \\
(\%)\end{array}$ & $\begin{array}{c}A \\
n \\
(\%)\end{array}$ & $\begin{array}{c}B \\
n \\
(\%)\end{array}$ & \\
\hline & $\begin{array}{c}11 \\
(6.9)\end{array}$ & $\begin{array}{c}8 \\
(6.8)\end{array}$ & $\begin{array}{c}3 \\
(8.3)\end{array}$ & $\begin{array}{c}6 \\
(5.0)\end{array}$ & $\begin{array}{c}28 \\
(5.2)\end{array}$ \\
\hline $2-5$ & $\begin{array}{c}15 \\
(9.6)\end{array}$ & $\begin{array}{c}18 \\
(15.0)\end{array}$ & $\begin{array}{c}19 \\
(14.6)\end{array}$ & $\begin{array}{c}15 \\
(12.6)\end{array}$ & $\begin{array}{c}67 \\
(12.8)\end{array}$ \\
\hline $6-10$ & $\begin{array}{c}35 \\
(22.3)\end{array}$ & $\begin{array}{c}29 \\
(24.1)\end{array}$ & $\begin{array}{c}29 \\
(22.1)\end{array}$ & $\begin{array}{c}30 \\
(25.2)\end{array}$ & $\begin{array}{c}123 \\
(23.4)\end{array}$ \\
\hline $11-15$ & $\begin{array}{c}15 \\
(9.6)\end{array}$ & $\begin{array}{c}8 \\
(6.7)\end{array}$ & $\begin{array}{c}10 \\
(7.6)\end{array}$ & $\begin{array}{c}9 \\
(7.6)\end{array}$ & $\begin{array}{c}42 \\
(8.0)\end{array}$ \\
\hline $16-30$ & $\begin{array}{c}49 \\
(31.2)\end{array}$ & $\begin{array}{c}26 \\
(21.7)\end{array}$ & $\begin{array}{c}21 \\
(16.0)\end{array}$ & $\begin{array}{c}17 \\
(14.8)\end{array}$ & $\begin{array}{c}113 \\
(21.4)\end{array}$ \\
\hline 31 or + & $\begin{array}{c}32 \\
(20.4)\end{array}$ & $\begin{array}{c}31 \\
(25.7)\end{array}$ & $\begin{array}{c}49 \\
(37.4)\end{array}$ & $\begin{array}{c}42 \\
(35.3)\end{array}$ & $\begin{array}{c}154 \\
(29.2)\end{array}$ \\
\hline Total & $\begin{array}{c}157 \\
(100.0)\end{array}$ & $\begin{array}{c}120 \\
(100.0)\end{array}$ & $\begin{array}{c}131 \\
(100.0)\end{array}$ & $\begin{array}{c}119 \\
(100.0)\end{array}$ & $\begin{array}{c}527 \\
(100.0)\end{array}$ \\
\hline
\end{tabular}


Table 2 shows the carriage of entcropathogens distributed by age in both groups of study regardless of their SES. Positive cases were more frequent, in the total for each age group, in Group A than in Group B $(\mathrm{p}<0.05)$. There was a tendency for there to be carriers between the ages of 6 and 15 in Group A than in Group B.

Table 2. Enteropathogen carriage in families with children who had (A) or had not had (B) Typhoid Fever

\begin{tabular}{cccc}
\hline & \multicolumn{3}{c}{ Groups } \\
\cline { 2 - 3 } Age & $\mathrm{A}$ & $\mathrm{B}$ & Fisher Test \\
\cline { 2 - 3 } & $\%$ & $\%$ & $\mathrm{P}$ \\
\hline $1-5$ & $\begin{array}{c}23.2 \\
(n=43)\end{array}$ & $\begin{array}{c}10.2 \\
(n=39)\end{array}$ & $<.101$ \\
$6-15$ & $\begin{array}{c}13.4 \\
(n=89)\end{array}$ & $\begin{array}{c}5.2 \\
(n=76)\end{array}$ & $<.08$ \\
\hline Total (All ages) & $\begin{array}{c}13.8 \\
(n=288)\end{array}$ & $\begin{array}{c}8.3 \\
(n=239)\end{array}$ & $<.05$ \\
& & & $x^{2}=4.029$ \\
& & & 1 d.f. \\
\hline
\end{tabular}

The bacterial species isolated are shown in Table 3. A significantly higher frequency of enteropathogens was observed in Group A, both in the low and the high SES. The enteropathogens most frequently detected (in decreasing frequency) werc: E. coli, mainly the classic serotypes, Shigella ssp, Salmonella ssp and Campylobacter jejuni. When the groups A and B, as wholes, are compared the difference is significant. Group A showed more carriers than did Group B ( $p<0.05$ ).

Table 4 shows the hand markers of individuals who cooked for families with children who had had (A) or had not had (B) TF. The bacteria isolated from the hands of individuals who cooked for the family ("hand markers") were E. coli and Staphylococcus aureus. The former was detected in $39.5 \%$ in Group A and $16.1 \%$ in Group B, the difference being significant $(p<0.02)$. Individuals of Group A had a tendency to present more positive results for Staphylococcus aurcus $(p<0.09)$. More than one person prepared meals in families of both groups, generally the mother and/or the grandmother in the low SES and the maid or the mother in the high SES. Families of Group A had higher carriage rates of enteropathogens than those of Group B (52.5\% vs 30\%, p < 0.05). (Table 5).

Table 3. Bacterial Species identified in the stool cultures of individuals from low and high SES families with children who had (A) or had not had $(B)$ Typhoid Fever

\begin{tabular}{|c|c|c|c|c|c|c|}
\hline \multirow[b]{3}{*}{$\begin{array}{l}\text { Groups } \\
\text { Bacterial } \\
\text { Species }\end{array}$} & \multicolumn{2}{|c|}{ Socioeconomic } & \multicolumn{2}{|c|}{ Stratum } & \multicolumn{2}{|c|}{ Total } \\
\hline & Low & High & Low & High & Low & High \\
\hline & $\begin{array}{c}A \\
(n=157) \\
n\end{array}$ & $\begin{array}{c}B \\
(n=120) \\
n\end{array}$ & $\begin{array}{c}A \\
(n=277) \\
n\end{array}$ & $\begin{array}{c}B \\
(n=250) \\
n\end{array}$ & $\begin{array}{c}A \\
(n=434)^{*} \\
n\end{array}$ & $\begin{array}{c}B \\
(n=370)^{*} \\
n\end{array}$ \\
\hline \multicolumn{7}{|l|}{$\begin{array}{l}\text { E. coli } \\
\text { - Classic }\end{array}$} \\
\hline serotypes & 8 & 8 & 7 & 4 & 15 & 12 \\
\hline - Toxigenic & - & - & 2 & - & 2 & - \\
\hline - Invasive & 1 & - & 3 & 1 & 4 & 1 \\
\hline \multicolumn{7}{|l|}{ Shigella } \\
\hline - flexneri & 3 & 3 & 1 & - & 4 & 3 \\
\hline - boydii & 4 & - & 1 & - & 5 & - \\
\hline - sonei & 2 & - & 2 & 1 & 4 & 1 \\
\hline \multicolumn{7}{|l|}{ Salmonella } \\
\hline$-s s p$ & 2 & - & - & - & 2 & - \\
\hline - enteritidis & 1 & 1 & - & - & 1 & 1 \\
\hline - typhi & - & - & 1 & - & 1 & - \\
\hline - paratyphi B & - & - & 1 & - & $i$ & - \\
\hline \multicolumn{7}{|l|}{ Campylobacter } \\
\hline jejuni & 1 & 2 & - & - & 1 & 2 \\
\hline Total & 22 & 14 & 18 & 6 & $40^{*}$ & $20^{*}$ \\
\hline
\end{tabular}

* Positive vs negative $x^{2}=4.043 P<.051$ d.f. 
Table 4. Hand Markers of individuals who cooked in families with children who had (A) or had not had (B) TF

\begin{tabular}{lccc}
\hline Markers & $\mathrm{A}$ & $\mathrm{B}$ & Fisher test \\
& $\%$ & $\%$ & $\mathrm{P}$ \\
\hline E. coli & $\begin{array}{c}39.5 \\
(n=48)\end{array}$ & $\begin{array}{c}16.1 \\
(n=44)\end{array}$ & $<.02$ \\
$\begin{array}{l}\text { Staphylococcus } \\
\text { Aureus }\end{array}$ & $\begin{array}{c}14.0 \\
(n=43)\end{array}$ & $\begin{array}{c}2.0 \\
(n=49)\end{array}$ & $<.09^{*}$ \\
\hline
\end{tabular}

- Tendency
Table 5. Number (\%) of families with children who had (A) or had not had (B) Typhoid Fever

\begin{tabular}{lccccccc} 
& \multicolumn{9}{c}{ Groups } & & \\
\cline { 2 - 6 } Families & $n$ & A & \multicolumn{2}{c}{ B } & \multicolumn{2}{c}{ Total } \\
& $n$ & & $n$ & $\%$ & $n$ & $\%$ \\
\hline Carriers & 21 & 52.5 & 12 & 30 & 33 & 41.3 \\
Non-carriers & 19 & 47.5 & 28 & 70 & 47 & 58.7 \\
\hline Total & 40 & 100.0 & 40 & 100 & 80 & 100.0 \\
\hline
\end{tabular}

$x^{2}=4.356 p<.051 d f$

Table 6. Relationship between the adequacy of hygiene habits according to the different indexes and the presence of carriers in the families studied (in percentages)

\begin{tabular}{|c|c|c|c|c|}
\hline $\begin{array}{c}\text { Adequate hygiene } \\
\text { habits }\end{array}$ & $\begin{array}{c}\text { Carriers } \\
(n=33) \\
\%\end{array}$ & $\begin{array}{c}\text { Non-carriers } \\
(n=47) \\
\%\end{array}$ & $x^{2} 0$ & $\begin{array}{c}1 \mathrm{df} \\
p\end{array}$ \\
\hline \multirow{7}{*}{$\begin{array}{l}\text { Child doesn't buy } \\
\text { Unwrapped sweets } \\
\text { Child purchasing } \\
\text { Index } \\
\text { Toilet observation } \\
\text { Index (50-100\%) } \\
\text { Sink observation } \\
\text { Index (75-100\%) } \\
\text { Washing Hands } \\
\text { Index (50-100\%) } \\
\text { Food preparation general } \\
\text { Index (70-100\%) } \\
\text { Fecal-oral cycle } \\
\text { (340-400\%, } 4 \text { indexes) }\end{array}$} & 57.8 & 78.7 & 4.555 & $<.05$ \\
\hline & 39.4 & 70.3 & 7.6 & $<.01$ \\
\hline & 75.7 & 91.5 & $F^{*}$ & $<.05$ \\
\hline & 48.5 & 68.0 & 3.103 & $<.10>.05$ \\
\hline & 69.6 & 87.2 & $F^{*}$ & $<.05$ \\
\hline & 75.7 & 91.4 & 4.902 & $<.05$ \\
\hline & 42.4 & 68.0 & $F^{*}$ & $<.01$ \\
\hline
\end{tabular}

- As frequency distribution does not allow the calculation of $x^{2}$ we the Fisher test was used.

Table 6 shows the relationships between adequate hygiene habits and "carrier families". These latter showed a significantly higher association with inadequate hygiene habits.

\section{Discussion and Conclusions}

This study seeks to show how intrafamily contamination can facilitate the fecal-oral cycle. Families with a child who had had TF were investigated since this condition serves as a model of a fecal-oral cycle transmitted disease. If the environment in which the child is growing up is known, it may be possible to forecast the discases they may catch and efforts can then be madc to avoid those related to the fecal-oral cycle.

It should be pointed out that the structure of the family groups and the age of their members were similar in both groups of study making the bacteriological samplings comparable (Table 1).
"Carrier families" were found significantly more frequently among those with a child who had had TF, regardless of their socioeconomic status. This suggests that the members of these families have inadequate hygiene habits that facilitate the fecal-oral cycle. It is to be noted too, that in two of the high SES families with a child who had had TF there were, in addition, individuals who were Salmonclla typhi and Paralyphi B carriers. In one case it was the mother and in the other an 18. ycar-old sister. This is in agrcement with recent studies which show that most Salmonella typhi carriers are women ${ }^{18}$. There was not a single case of this kind anong low SES families.

With respect to bacteriological cultures of hands ("hand markers") of individuals who prepared meals, the same was found to be true: families who had had a child with TF were significantly more contaminated with $E$. coli than the others. This again supports the idea that higher contamination in these families is found inside the home. In studies 
made on food handlers who work in restaurants or hospitals in Santiago a very high rate of carricrs of bacteria and parasites was found 10,19,28,29. These individuals are, obviously, a source of contagion for those who depend on their services.

The effective hygiene behaviors obscrved in families who had a lower incidence of carricrs strongly suggests the association between these two findings. Incorrect hygiene habits associated with higher carrier rates included those of the child itself ( $p<0.05$ ), of the family in general, of those who prepare the food $(p<0.05)$ and of those linked to the fecal-oral cycle $(p<0.01)$. As to the purchase of unwrapped sweets, it is comonplace for peddlers to display their wares in open baskets, which attracts flies as well as encouraging fingering by both children and peddler.

The incorrect habits of those family members who prepare food enable the fecal-oral cycle to operate efficiently within the family group. It is possible that, in the high SES, results are inlluenced by the individuals of low SES who work for them as maids. However, they can also be interpreted as indicating that the housewife is not stringent enough about greater clcanliness and care in the preparation of food by the maid.

The results of this study corroborate those obtained in surveys on diarrhoeal discase in which high carrier rates of bacterial enteropathogens $s^{4,14}$ have been shown in asymptomatic children.

This is probably related to high environmental contamination.

These results emphasize the nced to tcach proper hygiene habits to familics with members who have infectious disease acquired throug the fecaloral cycle, specially in families with young children. These educational programs should be addressed to the entire population, including that of the high SES, since high SES does not guarantee adequate hygienic habits.

ALVAREZ, M. L. et al. Hábitos de higiene e portadores em familias que tiveram uma criança com fcbre tifóide. Rev. Saúde públ., S. Paulo, 26: 75-81, 1992. Objetivou-se esnudar a relação entre qualidade dos hábitos de higiene e presença de portadores de agentes bacterianos enteropatogenos, em familias que tiveram ou não, uma criança com febre tifóide (FT). A amostra esteve constituída por 80 famílias: 40 com a presença , em cada uma, de uma criança com FT (Grupo A) e 40 em que nem as crianças e seus pais nunca tiveram historia de FT (Grupo B). Em cada grupo, 20 famílias pertenciam ao nível socioeconômico (NSE) baixo c 20 ao NSE alto. Para avaliar o NSE e os hábilos de higiene da criança foi utilizada entrevista estruturada; para medir os hábitos higiênicos da família (banho, cozinha e preparo dos alimentos) foram utilizadas obser- vaçõcs estruturadas; e os estudos bacteriológicos foram realizados $\mathrm{cm}$ amostras de fezes e marcadores de mão. Os resultados mostraram que no grupo $A$ houve maior freqüência de portadores que no $B$. As espécies bacterianas foram significativamente mais freqüentes no Grupo A que no B (nas fezes: E. coli, serotipos clássicos, Shigella ssp; e cm marcadores de mão: $E$. coli). As famílias do grupo A tiveram taxas altas de microorganismos que as do grupo B. Foi encontrada associação significativamente alta entre hábitos inadequados de higiene $c$ as familias portadoras. Os resultados mostraram a necessidade de ensinar hábilos específicos de higiene adequada a toda a população, pois somente o fato de pertencer ao NSE alto não previne os hábitos de higiene inadequados.

Descritores: Febre tifóide, epidemiologia. Portador. Família. Higiene.

ALVAREZ, M. L. et al. [Hábitos de higiene y portadores en familias que tuvieron un niño con fiebre tifoídea]. Rev. Saúde públ., S. Paulo, 26: 75-81, 1992. El objetivo de este estudio fue investigar las relaciones entre la presencia de portadores de agentes bacteriales enteropatógenos y la calidad de los hábitos de higiene en familias que han tenido o no un niño con fiebre tifoídea (TF). La muestra estuvo formada por 80 familias: 40 en las que hubo un niño con FT (grupo A) y 40 en las que ni los niños y sus padres habían tenido una historia de FT (grupo B). En cada grupo 20 familias pertenecían al nivel socicconómico bajo (NSE) y 20 al NSE alto. Se usó una entrevista estructurada para evaluar el NSE, los hábitos de higiene del niño; observaciones estructuradas para medir los hábitos de higiene de la familia (baño, cocina y preparación de alimentos) y estudios bacteriológicos (muestras fecales y marcadores de mano). Los resultados señalan que los portadores fueron más frecuentes en el grupo A que en el B. Las especies bacterianas fucron significativamente más en el grupo $A$ que en el B (muestras fecales: E. coli, serotipos clásicos, Shigella ssp, y marcadores de mano: $E$. coli). Las familias del grupo A tenían tasas más altas de portación que aquellas del grupo B. Finalmente existe una asociaión signifieativamente alta entre los hábitos inadecuados de higiene y las familias portadoras. Estos resultados muestran la necesidad de enscñar hábitos específicos de higiene adecuada a toda la población, porque el solo hecho de pertenecer al NSE alto no previene los hábitos de higiene inadecuados.

Descriplores: Febre tifoídca, epidemiologia. Portador. Familia. Higienc.

\section{Referências Bibliográficas}

1. AlVARE7., M. L.; MUZZZO, S.; IVANOVIC, D. Escala para medición del nivel sociocconómico en el área de la salud. Rev. méd. Chile, 113: 243, 1985.

2. ARAYA, M.; PACIIECO, I.; ESPINOZA, J.; BRUNSER, O. Enteroparásitos en precscolares aparentemente sanos 
de nivel socioeconómico alto. Rev. chil. Nutr., 10: 2319, 1982.

3. ARAYA, M.; FIGUEROA, G.; ESPNOZA, J.; MONTESINOS, N.; SPENCER, E.; BRUNSER, O. Acute dirthoeal disease in children under 7 years of age in a periurban slum of Santiago, Chile. J. Ilyg., 95:457-67, 1985.

4. ARAYA, M.; FIGUEROA, G.; ESPINOZA, J.; ZARUR, $X$.: BRUNSER, $O$. Acute diarrhea and carrier state in children preschoolers of the low and high sociocconomic strata. Acta pediatr. scand. 75: 645, 1986.

5. BLACK, R. E.; BROWN, K. H.; BECKER, S.; ABDUL. ALIM, A. R. M.; IMDABUL, H. Longitudinal studies of infectious diseases and physical growth of children in rural Bangladesch. II - Incidence of diarthea and association with known pathogens. Amer. J. Epidem., 115: 305.14, 1982.

6. BLACK, R. E.; CISNEROS, L.; BANFI, A.; LOBOS, H.; RODRIGUEZ, H. Case-control study to identify risk factors for pediatric endemic typhoid fever in Santiago, Chile. Bull. Wld Hlth Org., 63: 899-904, 1985.

7. BRUNSER, O.; FIGUEROA, G.; ARAYA, M.; ESPNNO ZA, J. Infections and diartheal disease. In: White, L. \& Selvey, N. eds. Malnutrition: determinants and consequences. New York, Alan R. Liss, 1983. p. 259-70.

8. CABELLO, F.; AGÜERO, M. E.; FERNÁNDEZ, M. E. Epidemia de fiebre tifoidea en Chile: aspectos ecológicos y microbiológicos. Rev. méd. Chile, 112: 826-8, 1984.

9. CAMPBELL, D. \& STANLEY, J. Diseños experimentales y cuasi experimentales en la investigación social. Buenos Aires, Amorrortu Ed., 1970.

10. DALL ORSO, L. M.; PINILLA, N.; PARRA, G.; BULL, F. Parásitos y protozoos comensales intestinales en manipuladores de alimentos del área central de la ciudad de Concepción, Chile. Bol. chil. Parasit, 30: 30-1, 1975.

11. ESPLNOZA, J.; ALTIERI, A. M.; PACHECO, I.; LABRIN, S.; ARAYA, M.; BRUNSER, O. Infección parasilaria asintomática en lactantes menores de 6 meses. Rev. chil. Pediat., 56: 427, 1985.

12. FIGUEROA, G.; BRUNSER, O.; ARAYA, M.; ESPNOZA, J.; MONTESINOS, N. Marcadores de contaminación macrobiológica del individuo y de su ambiente. [Apresentado a $19^{\mathrm{a}}$ Reunión Anual de la Sociedad Latinoamericana de Investigaciones Pediátricas, Quito, Ecuador, 1981]

13. FIGUEROA, G.; ARAYA, M.; ESPINOZA, J.; TRONCOSO, M.; BRUNSER, O. Número de muestras fecales y recuperación de enteropatógenos en sujetos con diarrea aguda. Rev. méd. Chile, 110: 1015-6, 1982.

14. FTGUEROA, G.; TRONCOSO, M.; ARAYA, M.; ESPINOZA, J.; BRUNSER, $O$. Enteropathogens carriage by healthy individuals living in a contaminated area with poor sanitation. J. Hyg., 91: 499, 1983.

15. FRENZEL, A. M.; TORRES, P.; GUERRERO, S.; GESCHE, W.; MONTEFUSCO, A.; MARÍN, F. Parasitosis intestinal en lactantes y su relación con la infección de sus manipuladores de alimentos y el saneamiento am. biental. Rev. méd. Chile, 107: 343-5, 1979.

16. GIANNELLA, R. A. Suckling mouse model for detection of heat stabel Escherichia coli enterotoxin: characteristics of the model. Infect. Immun., 14: 95-9, 1976.

17. LENNETTE, E.H.; BALOWS, A.; HAUSLER, W.J.; SIIA-
DOMY, A. J,, eds. Manual of clinical microbiology. 4th ed. Washington, DC, American Socicty for Microbiology, 1985.

18. LEVINE, M.; BLACK, R.; LANATA, C.; CHILEAN TYPHOID COMMITTEE. Precise estimation of the number of chronic carriers of Salmonella typhi in Santiago, Chile: an endemic area. J. infect. Dis., 146: 724-6, 1982.

19. LYNCH, B.; SEIPULVEDA, A.; LILLO, R.; DIAZ, C.; DLNAMARCA, $O$. Investigación de portadores de Staphylococcus aureus en manipuladores de alimentos. Rev. méd. Chile, 102: 277-8, 1974.

20. MATA, L. J. \& URIRUTIA, J. J. Intestinal colonization of breastfed children in a rural area of low sociocconomic level. Ann. New York Acad. Sci., 176: 93, 1971.

21. MATA, L. J. The children of Santa Maria Cauque: a prospective field study of health and growth. Cambridge, Mass., M. I. T. Press, 1978.

22. MEDINA, E. \& IRARRÁZAVAL, M. Fiebre tifoidea en Chile: consideraciones epidemiológicas. Rev. méd. Chile, 111: 609, 1983.

23. MINISTERIO DE SALUD DE CHILE. Boletin de Vigilancia Epidemiológica. Santiago, 9(11/12), 1981; 10(12), 1982; 11(12), 1983/1984; 12(12), 1985; 13(12), 1986.

24. MINISTERIO DE SALUD DE CHILE, Anuário de Enfermedades de Notificación Obligatoria. Santiago, 1977 1980.

25. MORRIS, J. G.; FERRECIO, C.; GARCIA, J.; LOBOS, H.; BLACK, R. E.; RODRIGUEZ, H.; LEVINE, M. M. Typhoid fever in Santiago, Chile: a study of household contacts of pediatric patients. Amer.J.trop. Med. Ilyg., 33: $1198,1984$.

26. NERVI, 1.; RADDATS, A.; ZAMORANO, N. Estimation of the number of chronic carriers of Salmonella typhi in Santiago. J. infect. Dis., 149: 124-6, 1984.

27. RISTALNO, P. A.; LEVINE, M. M.; YOUNG, C. R. Improved Gm 1 - Iinzyme-Linked Immunosorbent essay for detection of Escherechia coli heat-labile enterotoxin. J. clin. Microbiol., 18: 808, 1983.

28. REYES, M. H. \& MUNOZ, V. Enteroparasitosis en manipuladores de alimentos en hospitales. Rev. méd. Chile, 103: 477, 1975.

29. REYES, HI.; OLEA, M.; HERNÁNDEZ, R. Enteroparasitosis en manipuladores de alimentos del área de salud Oriente de Santiago. Bol. chil. Parasit., 27: 115-6, 1972.

30. SEARS, S. D.; FERRECIO, C.; LEVINE, M. M.; CORDANO, M. A.; MONREAL, J.; BLACK, R.E.; D'OTTONE, K.; ROWE, B.; CIHLEAN TYPHOID COMMITTEE. The use of Moore Swabs for isolation of Salmonella typhi from irrigation water in Santiago, Chile. J. infect. Dis., 149: 640-2, 1984.

31. SKIRROW, M.B. Campylobacter enteritis: a "new" disease. Brit. med. J., 2: 9.11, 1977.

32. TORO, A. \& RISTORI, C. Enfermedades transmisibles. Morbidad notificada por algunas enfermedades transmisibles, Chile, 1977-1986. Bol. epidemiol., Santiago, 14: 2-7, 1987
Received for publication in 26/6/1991 Reviewed in 2/1/1992 Accepted for publication in 17/2/1992 